\title{
ZASTOSOWANIE SZTUCZNEJ INTELIGENCJI W POZASĄDOWYM ROZWIĄZYWANIU SPORÓW CYWILNYCH
}

\section{Wstęp}

Sztuczna inteligencja (ang. artificial intelligence, AI) - rozumiana jako naśladowanie przez maszyny, zwłaszcza systemy komputerowe, procesów decydujących o inteligencji człowieka ${ }^{1}$ - opanowuje nowe obszary życia społecznego i gospodarczego, w tym problematykę rozstrzygania i rozwiązywania sporów cywilnych. Jednak trend ten nie może zostać pozbawiony odpowiednich ram prawnych i etycznych, zwłaszcza w zakresie weryfikacji jakości usług świadczonych przez maszyny w oparciu o algorytmy pozwalające na wspomaganie - albo wręcz zastępowanie - ludzkiego procesu podejmowania decyzji. Zauważają to prawodawcy, na razie przede wszystkim na poziomie soft law, czego przykładem jest Rezolucja Parlamentu Europejskiego zawierająca zalecenia dla Komisji w sprawie przepisów prawa cywilnego dotyczących robotyki² ${ }^{2}$ u której podstaw znalazło się stwierdzenie, że dalszy rozwój i rosnące wykorzystanie automatycznego podejmowania decyzji opartego na algorytmach niewątpliwie wywrze wpływ na wybory dokonywane zarówno przez osoby fizyczne (np. przedsiębiorców i użytkowników Internetu), jak i na organy administracyjne, sądowe lub inne organy publiczne

* Dr hab., prof. Uniwersytetu Szczecińskiego; e-mail: kinga.flaga-gieruszynska@ usz.edu.pl, ORCID ID: https:/ / orcid.org/0000-0001-5177-4450”0000-0001-5177-4450.

1 Zob. Stownik [on-line], serwis internetowy SI Sztuczna Inteligencja, https:// www.sztucznainteligencja.org.pl/slownik/ [dostęp: 20.07.2019 r.].

2 Rezolucja Parlamentu Europejskiego z dnia 16 lutego 2017 r. zawierająca zalecenia dla Komisji w sprawie przepisów prawa cywilnego dotyczących robotyki (2015/2103(INL)), Dz. Urz. UE C 252 z 18.07.2018, s. 239-257. 
przy podejmowaniu ostatecznych decyzji dotyczących konsumentów, biznesowych lub innych o charakterze rozstrzygającym. W preambule rezolucji pojawia się również wskazanie, że w procesie automatycznego podejmowania decyzji opartego na algorytmach konieczne jest zapewnienie zabezpieczeń oraz możliwości kontroli i weryfikacji przez człowieka ${ }^{3}$. Odnosi się to zarówno do etapu gromadzenia danych, ich wykorzystywania na potrzeby określenia dostępnych opcji rozwiązywania sporów cywilnych, a jak i finalnego procesu wyboru rozwiązania optymalnego w konkretnych uwarunkowaniach podmiotowych i przedmiotowych. Wskazane stanowisko, co do ram prawnych i etycznych rozwoju AI, musi być zaakceptowane zarówno co do ADR (Alternative Dispute Resolution), w których sztuczna inteligencja może stanowić narzędzie wspomagające, jak i co do ich elektronicznej mutacji - ODR (Online Dispute Resolution), gdzie AI staje się głównym medium kształtującym przebieg i wynik postępowania.

Tym samym rozwój robotyki w obszarze stosowania prawa i rozwiązywania sporów pozostaje $\mathrm{w}$ głównym nurcie postulatów zgłaszanych w zakresie aspektów etycznych funkcjonowania sztucznej inteligencji w życiu codziennym ludzkości. W soft law ponad to wskazuje się, że w toku rozwoju sztucznej inteligencji należy się kierować zasadami: przynoszenia korzyści - roboty powinny służyć najlepszemu interesowi człowieka; nieszkodliwości - zasada „po pierwsze nie szkodzić”, zgodnie z którą roboty nie powinny krzywdzić ludzi; autonomii - wyrażającej się w zdolności do podjęcia świadomej, niewymuszonej decyzji na temat zasad interakcji z robotami; sprawiedliwości - co do sprawiedliwego rozłożenia korzyści związanych z robotyką, a w szczególności przystępność cenowa robotów do opieki domowej i opieki zdrowotnej ${ }^{4}$. W obszarze omawianym w niniejszym opracowaniu szczególnie istotna jest docelowa dostępność AI na potrzeby rozwiązywania (rozstrzygania) sporów cywilnych w drobnych sporach, np. z udziałem konsumentów i pacjentów. Z tego zresztą prawodawca unijny zdaje sobie sprawę, bowiem już tworzy podwaliny pod tego

3 Zob. tamże.

4 Zob. preambuła Kodeksu postępowania etycznego dla inżynierów robotyki, załącznik do rezolucji Parlamentu Europejskiego z dnia 16 lutego 2017 r. zawierającej zalecenia dla Komisji w sprawie przepisów prawa cywilnego dotyczących robotyki (2015/2103(INL)), Dz. Urz. UE C 252 z 18.07.2018, s. 239-257, http:/ / www.europarl.europa.eu/doceo/document/TA-8-2017-0051_PL.html?redirect [dostęp: 28.07.2019 r.]. 
rodzaju narzędzia w postaci portalu ODR w sprawach konsumenckich (Europejska platforma internetowego rozstrzygania sporów) ${ }^{5}$.

Mówiąc o ADR, należy przede wszystkim brać pod uwagę mediację (także koncyliację), arbitraż i negocjacje. W doktrynie wskazuje się ponadto tzw. formy mieszane, czyli hybrydalne, powstające z połączenia różnych elementów form podstawowych oraz procesu sądowego, takie jak: med-arb, arb-med, mini-trial (minirozprawa), summary jury trial (skrócone postępowanie przed ławą przysięgłych), early neutral evaluation - ENE (ocena sprawy przez neutralną osobę trzecią), private judging (rent-a-judge, prywatny sędzia), ombudsman itp. ${ }^{6}$ Ze względu na zróżnicowanie kryteriów klasyfikacji $\mathrm{w}$ literaturze przedmiotu pojawia się szereg podziałów ADR na: 1) formy podstawowe, formy niepodstawowe; 2) formy związane z sądami, formy niezwiązane z sądami; 3) formy publiczne, formy prywatne; 4) formy sformalizowane, formy niesformalizowane; 5) formy dobrowolne, formy niedobrowolne; 6) formy o wiążącym charakterze rozwiązania sporu, formy o niewiążącym charakterze rozwiązania sporu; 7) formy wyróżnione ze względu na charakter ewentualnej interwencji osoby trzeciej; 8) formy stosowane w świecie rzeczywistym (offline ADR), formy wykorzystywane online 7 . Nie ulega wątpliwości, że podmioty pozostające w sporze, jeśli zdecydują się na jego polubowne rozstrzygnięcie, powinny wybrać optymalne rozwiązanie, tzn. sposób postępowania jak najlepiej dostosowany do konkretnych okoliczności, w jakich doszło do powstania konfliktu interesów ${ }^{8}$. Jednak niezależnie od formy, struktury organizacyjnej, zakresu zastosowania i innych czynników kształtujących konkretny ADR w każdym przypadku można a priori przyjąć, że potencjalnie sztuczna inteligencja może stanowić wsparcie dla jej działania,

5 Internetowe rozstrzyganie sporów [online], serwis internetowy Komisja Europejska, https:/ / ec.europa.eu/consumers/odr/main/index.cfm?event=main.home2.show\&lng=PL [dostęp: 28.07.2019 r.].

6 Szerzej zob. E. Gmurzyńska, Mediacja w sprawach cywilnych w amerykańskim systemie prawnym - zastosowanie w Europie i w Polsce, Warszawa 2007, s. 11-34; A. Kalisz, A. Zienkiewicz, Mediacja sądowa i pozasadowa. Zarys wykładu, Warszawa 2009, s. 36-39.

7 Zob. A. Kalisz, A. Zienkiewicz, Mediacja sq̨dowa i pozasadowa..., s. 39; M. Białecki, Klasyfikacja alternatywnych metod rozwiązywania sporów, w: M. Białecki, Mediacja w postępowaniu cywilnym, Warszawa 2012 [wyd. el. LEX].

8 Szerzej zob. R. Golat, Kiedy i jak doprowadzić do zawarcia ugody?, w: R. Golat, Polubowne rozstrzyganie sporów, Warszawa 2007 [wyd. el. LEX]. 
a w niektórych przypadkach stać się osią rozwoju alternatywnej metody rozwiązywania albo rozstrzygania sporów cywilnych.

Podstawowym celem badawczym niniejszej analizy jest ustalenie roli, jaką współcześnie i w przyszłości może odegrać sztuczna inteligencja w kreowaniu instrumentów stanowiących alternatywę (ale nie konkurencję) dla państwowego wymiaru sprawiedliwości i tradycyjnych form $\mathrm{ADR}^{9}$, które niekiedy nie spełniają wszystkich oczekiwań podmiotów poszukujących ochrony prawnej. W tym zakresie nadal istotne jest wyraźne rozdzielenie ADR i systemu wymiaru sprawiedliwości. Należy w pełni zaakceptować stanowisko A. Jakubiak-Mirończuk, która jest przeciwna włączaniu trybów ADR do systemu wymiaru sprawiedliwości, gdyż taki zabieg legislacyjny mógłby spowodować obciążenie wskazanych procedur tymi samymi wadami, które powodują dysfunkcję sądów ${ }^{10}$. Niewątpliwie na obecnym etapie rozwoju AI należy zastanowić się nad rolą, jaką może odegrać sztuczna inteligencja w pozasądowym rozwiązywaniu sporów cywilnych, biorąc pod uwagę dotychczasowe doświadczenia i rysujące się perspektywy z uwzględnieniem ewentualnych zagrożeń. Te ostatnie odnoszą się nie tylko do sfery technicznej (w szczególności nadzoru nad coraz bardziej samodzielną sztuczną inteligencją), ale również sfery społecznej, związanej z barierami

9 Stanowią one przedmiot licznych analiz w polskiej doktrynie, czego przykładem są następujące publikacje powstałe na pierwszym etapie rozwoju ADR w polskim systemie prawnym: K.W. Baran, Mediacja w sprawach z zakresu prawa pracy, Praca i Zabezpieczenie Społeczne 2006, nr 3; M. Białecki, Mediacja w postępowaniu...; A. Bieliński, Mediator w sprawach cywilnych - wybrane zagadnienia regulacji obcych i polskich, ADR. Arbitraż i Mediacja 2008, nr 3; Ł. Błaszczak, Alternatywne formy rozwiąywania sporów - analiza zjawiska na tle prawapolskiego, w: Czterdziestolecie kodeksu postępowania cywilnego. Zjazd Katedr Postępowania Cywilnego w Zakopanem (7-9.10.2005 r.), red. I. Ratusińska, Kraków 2006; E. Gmurzyńska, Kierunki rozwoju mediacji sądowej w sprawach cywilnych w USA $i$ w Europie, Europejski Przegląd Sądowy 2006, nr 11; Mediacje. Teoria i praktyka, red. E. Gmurzyńska, R. Morek, Warszawa 2009; R. Golat, Polubowne rozstrzyganie...; A. Gójska, V. Huryn, Mediacja w rozwiązywaniu konfliktów rodzinnych, Warszawa 2007; A. Jakubiak-Mirończuk, Alternatywne a sądowe rozstrzyganie sporów sądowych, Warszawa 2008; R. Morek, O potrzebie popularyzacji nowych koncepcji i metod rozwiazywania sporów, Palestra 2007, nr 7/8; R. Morek, Razem czy osobno: uwagi o znaczeniach pojęć mediacji i koncyliacji, w: Sądy polubowne i mediacje, red. J. Olszewski, Warszawa 2008; Arbitraż i mediacja. Praktyczne aspekty stosowania przepisów, red. J. Olszewski, Rzeszów 2007; H. Przybyła-Basista, Mediacje rodzinne w konflikcie rozwodowym, Katowice 2006; K. Weitz, Mediacja w sprawach gospodarczych, w: T. Wiśniewski i in., Postępowanie sadowe w sprawach gospodarczych, t. 7, Warszawa 2007.

10 Zob. A. Jakubiak-Mirończuk, Alternatywne a sądowe rozstrzyganie..., s. 15-16. 
psychologicznymi u ludzi, którzy obawiają się uzależnienia od sztucznej inteligencji, a w niektórych obszarach (np. na rynku pracy) - konkurencji ze strony AI.

\section{Sztuczna inteligencja a gromadzenie i przetwarzanie danych istotnych dla rozwiązania sporu cywilnego}

Pierwszym obszarem zagospodarowanym przez komputery - a dalej maszyny uczące - stało się gromadzenie i przetwarzanie danych gromadzonych w zasadzie w nieograniczonych ilościach (Big Data), co stanowi ogromną wartość w obecnym chaosie informacyjnym, w którym każdy obszar ludzkiej aktywności jest „atakowany” mnóstwem danych rozmaitej jakości z różnych, często niesprawdzalnych, źródeł. Problem ten odnosi się również do sporów cywilnych, zwłaszcza takich, w których źródłem ustalenia stanu faktycznego są dokumenty i świadectwa ludzkie gromadzone przez lata i odnoszące się do działalności szeregu podmiotów.

Jednym z przykładów zastosowania sztucznej inteligencji w tym obszarze stosowania prawa jest projekt LawGeex, który został stworzony w 2014 r. Służy on do oceny prawnej kontraktów. Użytkownik musi wprowadzić do programu umowę i niezwłocznie uzyskuje raport $\mathrm{z}$ analizą, która klauzula jest błędna. W testach porównawczych mających na celu zweryfikowanie trafności opinii maszyny wzięło udział 20 prawników. Dokładność wykonywania zadania przez LawGeex wynosiła 94\%, natomiast prawników jedynie $85 \%$. Jednocześnie przeanalizowano równie istotne kryterium czasu (mające przecież kluczowe znaczenie dla kosztów obsługi prawnej) i okazało się, że do analizy jednej umowy prawnicy potrzebowali przeciętnie 92 minut, a sztucznej inteligencji wystarczyło 26 sekund $^{11}$. Pokazuje to ogromne możliwości sztucznej inteligencji w zakresie wsparcia podmiotów zajmujących się rozwiązywaniem sporów cywilnych, również poza systemem wymiaru sprawiedliwości.

11 Zob. A. Mazurek, Najnowsze badania pokazuja jak sztuczna inteligencja pokonuje prawników [online], https://generacjasmart.pl/2018/05/21/sztuczna-inteligencjapokonuje-prawnikow/ [dostęp: 12.12.2018 r.]. 
W praktyce narzędzia odnoszące się do gromadzenia i przetwarzania danych mogą mieć zastosowanie na każdym etapie postępowania mającego na celu rozwiązanie (rozstrzygnięcie) sporu cywilnego, począwszy od czynności przygotowawczych, a skończywszy na etapie bezpośrednio poprzedzającym rozwiązanie (rozstrzygnięcie) sporu. Niewątpliwie ma to szczególne znaczenie przy zastosowaniu AI do alternatywnych metod rozwiązywania sporów cywilnych w obszarach sporów masowych, np. w ramach działalności portali zajmujących się sprzedażą lub pośredniczących w sprzedaży, które dokonują tysięcy transakcji i muszą rozwiązywać setki sporów niemal w czasie rzeczywistym.

Pierwszym obszarem tego rodzaju aktywności sztucznej inteligencji jest digitalizowanie, analizowanie, klasyfikowanie i ekstrakcja informacji z nieuporządkowanego lub częściowo uporządkowanego zbioru danych pozyskanych przez podmiot prowadzaccy postępowanie. Funkcja ta przekracza obszar mechanicznego gromadzenia i katalogowania danych, ponieważ obejmuje m.in.:

1) analizę przychodzących dokumentów i wydobycie metadanych istotnych dla sprawy;

2) nadawanie i późniejsze wykorzystywanie identyfikatorów przyporządkowanych poszczególnym dokumentom w celu ich właściwej alokacji;

3) rozpoznanie rodzaju pozyskiwanych dokumentów bez używania identyfikatora, włączając $\mathrm{w}$ to inteligentną alokację dokumentów, tworzenie plików i zadań w zakresie pracy z dokumentami (np. w celu wysłania wezwania do ich uzupełnienia);

4) opisywanie i kategoryzowanie skanowanych dokumentów;

5) wykrywanie danych na „pierwszą stronę” dokumentu lub jego załącznika, zdefiniowaną przez użytkowników systemu (np. na potrzeby tworzenia elektronicznych akt sprawy $)^{12}$.

Na dalszym etapie przetwarzania danych pojawia się zarządzanie dokumentami na potrzeby prowadzonych postępowan, $\mathrm{w}$ tym:

1) obrót dokumentami na podstawie „pierwszych stron” pojedynczych dokumentów po skanowaniu zbiorczym i rozdzielenie poszczególnych treści z załącznikami włącznie;

12 Zob. G. Stawa, How Is Austria Approaching AI Integration into Judicial Policies [online], https:/ / rm.coe.int/how-is-austria-approaching-ai-integration-into-judicial-policies-/16808e4d81 [dostęp: 16.07.2019 r.]. 
2) skonstruowanie opisu i klasyfikacji dokumentów poprzez harmonizację ich tytułów w zależności od ich znaczenia procesowego ustalonego na podstawie treści (np. pozwu, odpowiedzi na pozew w postępowaniu arbitrażowym);

3) inteligentna kreacja wewnętrznej elektronicznej struktury całych zbiorów dokumentów łącznie ze spisem treści;

4) kreowanie zorientowanych na stronę zbiorów dokumentów (np. odrębnej elektronicznej teczki dokumentów powoda);

5) budowanie linków do zasobów literatury i orzecznictwa;

6) tworzenie komponentów rozwiązań względnie rozstrzygnięć (np. na potrzeby ugody albo wyroku sądu arbitrażowego).

W obszarze przetwarzania danych duże znaczenie ma również analiza zebranego materiału dowodowego - istotna z perspektywy postępowań o charakterze adjudykacyjnym - który obejmuje:

1) opracowanie dużej liczby danych, w tym również wykrycie korelacji semantycznych;

2) automatyczne pozyskiwanie konkretnych informacji z dokumentów;

3) pozyskanie niezbędnej wiedzy o konkretnych stanach faktycznych bez podejmowania fizycznej kwerendy w tym zakresie;

4) ustalanie i weryfikację cech i wiarygodności źródeł informacji (np. na podstawie ich statusu oraz historii danych wykorzystywanych w innych postępowaniach);

5) ustalanie i wizualizację stanów faktycznych (np. symulacja przebiegu wypadku oparta na analizie dostępnych informacji);

6) konfiguracja i dostosowanie do konkretnej sprawy niezbędnych pytań na potrzeby uzupełnienia luk lub sprzeczności ww. stanie faktycznym.

Jak wynika z powyższych zestawień analiza i przetwarzanie danych mają szczególne znaczenie dla podmiotów prowadzących postępowania o charakterze adjudykacyjnym, które wydają rozstrzygnięcia wiążące dla stron. Dotyczy to arbitrażu i mieszanych form ADR, w których ten typ rozstrzygnięć się pojawia (np. med.-arb). W przypadku ADR o wyraźnym charakterze koncyliacyjnym analiza danych, w szczególności stanu faktycznego, z reguły nie ma znaczenia albo odgrywa znaczenie marginalne, bowiem to strony mają się porozumieć po ustaleniu swoich potrzeb, a nie ustalić, jakie są fakty. Co do tej sfery działalności sztucznej inteligencji wskazuje się jednak na istotne bariery, do których zalicza się przede 
wszystkim trudności AI z uczeniem się naturalnego języka (co może prowadzić do błędnego odczytu znaczenia treści dokumentów), a także efektywnym nadzorem nad jej czynnościami, które działałyby zapobiegawczo w zakresie ewentualnych błędów co do gromadzenia i przetwarzania danych $^{13}$. Nie bez znaczenia jest również problem nieweryfikowalnych źródeł informacji, które mogą dostarczać danych niskiej jakości czy też zwykłych ludzkich błędów występujących w strukturach tych źródeł (np. wydających dokumenty urzędowe), które nie zawsze maszyna - pozbawiona zdolności wychwytywania niuansów języka urzędowego - jest w stanie wykryć.

Nie zmienia to jednak faktu, że w tym zakresie zastosowanie sztucznej inteligencji może skutkować m.in.: zbudowaniem lepszych baz danych, również w partnerstwie z podmiotami zewnętrznymi; możliwością udostępniania danych $\mathrm{w}$ adekwatnym zakresie i $\mathrm{z}$ zachowaniem zasad bezpieczeństwa (np. na potrzeby analizy sądu na etapie postępowania zatwierdzającego ugodę albo rozpoznającego skargę o uchylenie wyroku sądu polubownego); możliwością dzielenia się wiedzą z innymi instytucjami (np. organami administracji publicznej w ramach systemu rozwiązywania problemów rodzinnych, jeśli AI po przeanalizowaniu danych uzna, że istnieje podejrzenie stosowania przemocy $\mathrm{w}$ rodzinie), a na etapie pośrednim - możliwością budowania nowych narzędzi wspierających tworzenie systemu zajmującego się rozwiązywaniem sporów cywilnych opartego na czynniku ludzkim (to support people-centric system $)^{14}$. W tym obszarze szczególnie przydatna jest funkcjonalność określana jako data crunching, pozwalająca na w pełni zautomatyzowaną analizę ogromnych zbiorów danych, dzięki której można podejmować decyzje. W ramach tych czynności AI sortuje dane, przetwarza, a następnie analizuje na potrzeby procesu decyzyjnego sztucznej inteligencji albo człowieka, które te uporządkowane dane otrzymuje do swojej dyspozycji.

13 Zob. R. Grove, AI, Machine Learning and the Administration of Justice in England and Wales: Prospects, Opportunities, Challenges [online], https:/ / rm.coe.int/ai-machine-learning-and-the-administration-of-justice-in-england-and-w/16808e4d87 [dostęp: 24.07.2019 r.].

14 Zob. tamże. 


\section{Sztuczna inteligencja a proces komunikowania się $\mathrm{w}$ sporach cywilnych}

Szczególnie trudnym obszarem odnoszącym się do funkcjonowania sztucznej inteligencji w kształtujących się współcześnie systemach pozasądowego rozwiązywania sporów cywilnych jest problem komunikacji werbalnej i niewerbalnej. W tym przypadku należy zwrócić uwagę na dwa podstawowe aspekty procesu komunikowania się: 1) w relacji między AI a stronami sporu i innymi podmiotami (mediatorem, arbitrem, biegłym itp.); 2) między stronami sporu, w którym AI pełni głównie funkcje monitorujące i analityczne.

W pierwszym przypadku - w relacjach z ludźmi - sztuczna inteligencja musi nauczyć się języka naturalnego, aby komunikować się z człowiekiem w sposób dla niego zrozumiały i niepowodujący błędnego odczytu przekazywanych komunikatów językowych. Co więcej, strona postępowania będąca w sytuacji wysoce stresogennej, jaką jest spór w fazie przedsądowej albo już sądowej (np. w wypadku mediacji ze skierowania sądu), nie przyjmie pozytywnie kontaktu z podmiotem, który formułuje pytania, rozwiązania itp. w sztucznym, hermetycznym języku. Najbardziej podstawową postacią stworzoną do tego rodzaju interakcji są tzw. chatboty. Klasyczny chatbot działa w sposób zautomatyzowany, bowiem odpowiada jedynie na pytanie wprowadzone do zasobów przez moderatora. Jednak $\mathrm{w}$ tym przypadku interakcje $\mathrm{z}$ reguły nie do końca satysfakcjonują użytkowników. Natomiast jeśli wykorzysta się umiejętność uczenia się maszyny, to zaczyna ona analizować pozyskane dane i uczy się na podstawie wcześniejszych interakcji, co pozwala na optymalne dopasowanie przebiegu rozmowy do jej kontekstu i potrzeb użytkownika. To otwiera drogę do pogłębionej komunikacji np. na potrzeby ustalania potrzeb stron $\mathrm{w}$ toku postępowania mediacyjnego.

Z tego względu tego rodzaju rozwiązania są szczególnie istotne w sytuacji, gdy sztuczna inteligencja pełni rolę doradczą względem podmiotów postępowania. Przykładem jest projekt Ross, który nabył umiejętność odczytywania pytań w języku naturalnym, analizy aktualnego stanu prawnego oraz zasobów literatury i orzecznictwa. Pozwala mu to na formułowanie hipotez odpowiedzi uszeregowanych według trafności ${ }^{15}$.

15 Zob. serwis internetowy Ross, https://rossintelligence.com/about.html [dostęp: 20.07.2019 r.]. 
Stanowi to ten typ interakcji, który ma decydujące znaczenie m.in. dla prawidłowego ustalenia faktograficznych podstaw sporu cywilnego albo rozwiązań znajdujących uzasadnienie w obowiązujących przepisach prawa. Nie sposób przy tym pominąć tego, że przetwarzanie języka naturalnego jest zadaniem niezwykle trudnym nawet dla najbardziej zaawansowanych programów, ponieważ język ludzki jest bardzo złożony i różnorodny: istnieją setki języków, dialektów i narzeczy, a każdy posiada unikalny zestaw reguł gramatycznych, własną składnię, frazeologię, słownictwo, interpunkcję i intonację. Jednak już obecnie maszyny są w stanie analizować nieporównanie więcej danych opartych na języku niż ludzie, nie męcząc się i zachowując większą precyzję i bezstronnośćc ${ }^{16}$. To otwiera kolejne obszary zastosowania sztucznej inteligencji, stosowane np. na potrzeby postępowania arbitrażowego takie jak: transkrypcja tekstu mówionego $\mathrm{w}$ czasie rzeczywistym, tłumaczenie i interpretacja dokumentów w czasie rzeczywistym czy tłumaczenie w czasie rzeczywistym wypowiedzi w różnych językach.

Jednak dopiero projekt Hanson Robotics Sophia pozwolił na rozwiązanie fundamentalnego problemu w zakresie nawiązywania relacji interpersonalnych, jakim jest okazywanie i odczytywanie ludzkich emocji ${ }^{17}$. Co więcej, nadanie maszynie ludzkiej postaci pozwoliło na wykorzystywanie przez nią niedostępnych dotąd środków komunikacji niewerbalnej (wyrazu twarzy, gestów itp.). Jednak nie stanowi to końcowego etapu rozwoju badań w tym obszarze, ponieważ nadal istnieje problem o charakterze analitycznym, odnoszący się do słabych umiejętności sztucznej inteligencji w zakresie oddzielania emocji od rzeczywistych potrzeb i interesów stron sporu cywilnego, co ma kluczowe znaczenie dla efektywności pozasądowych metod rozwiązywania sporów cywilnych. Jak zauważył S. Pinker, główną lekcją, wyniesioną z 35 lat badań nad SI jest to, że trudne problemy są łatwe, a łatwe problemy są trudne. Umysłowe zdolności czterolatka, które uważamy za oczywiste - rozpoznanie twarzy, podniesienie ołówka, przejście przez pokój - faktycznie rozwiązują jedne z najtrudniejszych inżynieryjnych

16 Zob. Stownik [online], serwis internetowy SI Sztuczna Inteligencja, https://www. sztucznainteligencja.org.pl/slownik/ [dostęp: 23.07.2019 r.].

17 Zob. serwis internetowy Hanson Robotics, https://www.hansonrobotics.com/ humanizing-ai/ [dostęp: 20.07.2019 r.]. 
problemów ${ }^{18}$. Ma to znaczenie nie tylko dla trafności analizy dokonywanej przez AI, ale również dla komfortu stron postępowania, którym zdecydowanie łatwiej rozmawia się $\mathrm{z}$ istotą ukształtowaną na podobieństwo człowieka.

Natomiast $w$ obszarze interakcji pomiędzy stronami postępowania sztuczna inteligencja na obecnym etapie odgrywa przede wszystkim istotną rolę aktywnego obserwatora, który może oceniać i analizować przebieg konwersacji, podejmując odpowiednie czynności wtedy, gdy uzna, że zaszły przesłanki ich przeprowadzenia. Przykładem tego rodzaju funkcji jest projekt CoParenter, którego istotą jest kształtowanie właściwych relacji pomiędzy rodzicami dzielącymi się opieką nad dzieckiem po rozwodzie albo w czasie separacji. Obok typowych funkcji dla tego rodzaju aplikacji, takich jak kalendarz zajęć dziecka, wykaz wydatków, pojawiają się funkcje obsługiwane przez AI. Sztuczna inteligencja monitoruje przebieg konwersacji prowadzonej przez rodziców co do szczegółów tej opieki według reguł charakterystycznych dla komunikatorów tekstowych. Jeśli w toku wymiany wiadomości tekstowych AI uzna, że pojawia się słownictwo obraźliwe, sugerujące agresję, może zastosować pauzę, aby dać stronie możliwość zastanowienia się, czy dane sformułowanie na pewno powinno dotrzeć do drugiej strony. Ponadto, jeśli ten "miękki” instrument nie rozwiąże problemu, a sztuczna inteligencja uzna, że dochodzi do eskalacji sporu w trakcie wymiany wiadomości, wysyła informację do centrum obsługi aplikacji w celu zapewnienia ingerencji ze strony mediatora-człowieka ${ }^{19}$. W tym przypadku mamy do czynienia z zastosowaniem tzw. analizy sentymentu. Jej istotą są automatyczne i półautomatyczne metody analizowania tekstu, których celem jest określenie stanu emocjonalnego jego autora i wpływu, jaki ten tekst może wywrzeć na emocje innych osób. Analiza sentymentu opiera się na rozwiązaniach wypracowanych $w$ dziedzinie przetwarzania języka naturalnego (NLP-natural language processing). Istnieją algorytmy pozwalające automatycznie klasyfikować teksty na te o pozytywnym i te o negatywnym wydźwięku emocjonalnym. Występują także algorytmy umożliwiające dokonywanie klasyfikacji bardziej złożonych, tj. zdolne

18 Zob. S. Pinker, The Language Instinct. How the Mind Creates Language, New York 2010, s. 14.

19 Zob. serwis internetowy: coParenter, https://coparenter.com/features/avoid-conflicts/ [dostęp: 20.07.2019 r.]. 
do wychwytywania stanów smutku, niepokoju, agresji, dumy czy miłości $^{20}$. W tym wypadku mamy do czynienia $\mathrm{z}$ typowym mechanizmem, który ma charakter wręcz prewencyjny - zapobiegający konfliktowi albo jego eskalacji.

Reasumując, obok komunikacji tekstowej, do tej pory dominującej w aktywności AI, pojawia się nowy - choć wciąż niedoskonały - obszar komunikacji niewerbalnej, którego podstawowym pozytywem staje się wzmocnienie komfortu psychicznego, opartego na podobieństwie do komunikowania się z inną istotą ludzką.

\section{Sztuczna inteligencja a pozasądowe rozwiązanie albo rozstrzygnięcie sporu cywilnego}

Ostatnim obszarem, który wymaga zasygnalizowania, jest etap wypracowania przez strony rozwiązania sporu, względnie wydania rozstrzygnięcia wiążącego strony. Dotychczasowe doświadczenia z zastosowaniem sztucznej inteligencji w wymiarze sprawiedliwości i innych procesach decyzyjnych odnoszących się do rozwiązywania sporów można uznać za niezwykle obiecujące. W badaniu obejmującym pulę 584 spraw zawisłych przed Europejskim Trybunałem Praw Człowieka (ETPCz) porównano rozstrzygnięcia wydane przez sędziów ETPCz do rozstrzygnięć zaproponowanych przez AI. Uzyskany wynik osiągnął poziom trafności oscylujący wokół 79\% rozstrzygnięć ${ }^{21}$. W kolejnym projekcie zbadano 7700 spraw prowadzonych przed Sądem Najwyższym Stanów Zjednoczonych i rozstrzygniętych w latach 1953-2013, a tym samym przeanalizowano ponad 68000 głosowań sędziowskich. W tym przypadku uzyskano 70,9\% tożsamych rozstrzygnięć22. I wreszcie w obszarze alternatywnych metod rozwiązywania sporów cywilnych na Uniwersytecie w Cambridge w 2017 r. w ramach projektu Case Cruncher Alpha

20 Zob. Stownik...

${ }^{21}$ Zob. N. Aletras i in., Predicting Judicial Decisions of the European Court of Human Rights: A Natural Language Processing Perspective [online], PeerJ Computer Science 2016, 2:e93, https:/ / doi.org/10.7717/ peerj-cs.93 [dostęp: 11.07.2019 r.].

${ }_{22}$ Zob. D.M. Katz, M.J. Bommarito II, J. Blackman, Predicting the Behavior of the Supreme Court of the United States: A General Approach[online], https://arxiv.org/abs/1407.6333 [dostęp: 23.07.2019 r.]. 
dokonano weryfikacji 775 spraw rzecznika finansowego, uzyskując 86,6\% trafności, a także przeanalizowano wyniki pracy panelu eksperckiego 100 doświadczonych prawników, przy czym w tym ostatnim przypadku osiągnięto zgodność jedynie na poziomie $66,3 \%{ }^{23}$. Powstaje oczywiste pytanie, jaka jest przyczyna ciągle występujących rozbieżności pomiędzy rozstrzygnięciami człowieka a propozycjami wygenerowanymi przez sztuczną inteligencję. W tym przypadku można mówić albo o jeszcze występującej niedoskonałości maszyny, która nie potrafi wychwycić wszystkich niuansów sprawy, mających wpływ na modyfikację końcowego rozwiązania sprawy albo o niedoskonałości natury ludzkiej, która zbyt często kieruje się emocjami, nie biorąc pod uwagę jedynie stanu faktycznego w "czystej postaci".

W tym przypadku podstawowe znaczenie dla wyników pracy AI ma analiza predykcyjna polegająca na wydobywaniu informacji z pozyskanych zbiorów danych po to, by na ich podstawie można było określić wzory i zaprognozować przyszłe zdarzenia albo trendy. W praktyce rozwiązaniem tego rodzaju jest wprowadzona na Łotwie możliwość rozpoznawania drobnych roszczeń (poniżej 2500 euro) bez udziału czynnika ludzkiego, którą obecnie stosuje się do ok. 60\% tej kategorii roszczeń. W postępowaniu tym pojawia się możliwość wykorzystania mediacji, jednak już w tradycyjnej formie ${ }^{24}$.

W omawianym obszarze zastosowania AI szczególne znaczenie ma również nabycie przez nią umiejętności wykraczających poza wydawanie racjonalnych osądów, co ma znaczenie dla jakości proponowanych (w trybach koncyliacyjnych) względnie narzucanych stronom (w trybach adjudykacyjnych) decyzji co do sporu cywilnego. W tym przypadku szczególnie istotne jest wykorzystanie praktycznych reguł poznawczych i emocjonalnych, które zapewnią właściwe odwzorowanie w procesie decyzyjnym emocji, intuicji i poczucia sprawiedliwości (co jest szczególnie istotne np. w sporach rodzinnych). Nie bez znaczenia jest również dostrzeganie

23 Zob. J. South, A. Rogers, What Might Artificial Intelligence Mean for Alternative Dispute Resolution? [online], serwis internetowy Kluwer Mediation Blog z dnia 30 sierpnia 2018 r., http:/ / mediationblog.kluwerarbitration.com/2018/08/30/might-artificial-intelligence-mean-alternative-dispute-resolution/ [dostęp: 13.05.2019 r.].

${ }_{24}$ Zob. S. Danis, J. Ruska, Latvia: State of Art: Where Are We, Where Do We Want to Go?, https:/ / rm.coe.int/latvia-state-of-art-where-are-we-where-do-we-want-to-go-/16808e4d84 [dostęp: 14.06.2019 r.]. 
nie tylko litery prawa, ale również społecznych skutków określonych decyzji $^{25}$. Dlatego w praktyce zauważalny jest intensywny rozwój systemów ekspertowych, tj. systemów zawierających w sobie wyspecjalizowaną wiedzę na temat określonego obszaru ludzkiej działalności, przy czym wiedza ta jest tak zorganizowana, że umożliwia systemowi wejście w interakcyjny dialog z użytkownikiem, w wyniku czego system może oferować rady lub podpowiadać decyzje, jak również objaśniać proces prowadzonego wnioskowania ${ }^{26}$. Dla złożonych postępowań arbitrażowych i mediacyjnych jest to funkcjonalność o wysokim stopniu przydatności.

W postępowaniach koncyliacyjnych, takich jak mediacja i koncyliacja, to strony wypracowują rozwiązania sporu cywilnego - więc w tym przypadku, zwłaszcza przy złożonych stanach prawnych i faktycznych, ciekawym sposobem zastosowania AI jest wskazywanie możliwych rozwiązań sporu na zasadzie analizy BATNA (ang. best alternative to a negotiated agrement). Obejmuje ona następujące czynności: 1) ustalenie wszystkich możliwych działań, jakie będzie można podjąć, jeśli porozumienie nie zostanie osiągnięte; 2) udoskonalenie najbardziej obiecujących rozwiązań i przekształcenie ich w praktyczne możliwości działania; 3) doskonalenie tymczasowego wyboru najlepszej z możliwości ${ }^{27}$. Z pewnością włączenie sztucznej inteligencji $\mathrm{w}$ ten proces zwiększa efektywność postępowań tego rodzaju, przyspieszając proces decyzyjny stron, a przede wszystkim eliminując propozycje ugodowe niezgodne z prawem albo sprzeczne z rzeczywistymi potrzebami stron.

Reasumując, sztuczna inteligencja ma pewne cechy dające możliwość efektywnego jej stosowania, również na etapie podejmowania ostatecznej decyzji w postępowaniu mającym na celu zakończenie sporu cywilnego. Należą do nich wygenerowana inteligencja wyróżniająca się przede wszystkim umiejętnością uczenia się, szybkie podejmowanie decyzji, umiejętność analizowania dużego zasobu danych w bardzo krótkim czasie, stabilność sposobu podejmowania decyzji, jasno określony

25 Zob. M. van der Put, B. Schellekens, Challenges and Opportunities of AI in the Judicial Systems. Reflections from the Netherlands [online], https://rm.coe.int/challenges-and-opportunities-of-ai-in-the-judicial-system-reflections-/16808e4d88 [dostęp: 13.07.2019 r.].

26 Zob. J. Nowak, Systemy ekspertowe. Podstawowe pojęcia, geneza, metody wnioskowania, PC-Shell [online], http://zsi.tech.us.edu.pl/ nowak/psiise/psiise_2.pdf [dostęp: 13.07.2019 r.].

27 Zob. Strategia BATNA [online], serwis internetowy Encyklopedia zarządzania, https://mfiles.pl/pl/index.php/Strategia_BATNA [dostęp: 22.07.2019 r.]. 
cel i wysokie umiejętności analityczne ${ }^{28}$. Jednak z drugiej strony, człowiek należycie wykonujący swoje zadanie w zakresie wsparcia procesu rozwiązania (jako np. mediator) względnie dokonujący rozstrzygnięcia sporu cywilnego (np. jako arbiter) wyróżnia się niezależnością osądu, profesjonalizmem, znajomością kontekstu społecznego oraz autorytetem. W konsekwencji przyszłością sztucznej inteligencji jest zminimalizowanie przewagi człowieka w tych obszarach, przy jednoczesnym wykorzystaniu posiadanego przez AI niezwykłego potencjału w zakresie przetwarzania i analizy danych.

Przeciwnicy rozszerzania zakresu stosowania AI w praktyce wymiaru sprawiedliwości, zawodów prawniczych oraz aktywności z nimi związanych, podnoszą, że angażowanie maszyn w proces decyzyjny w tej sferze życia społecznego stanowi m.in. zaprzeczenie idei prawa do sądu. Stanowisko to - reprezentowane m.in. przez T. Walsha - koncentruje się na stwierdzeniu, że "tylko ludzie, nie maszyny powinni mieć zadanie osądzać ludzi"29. Takie podejście do tej problematyki nie znajduje uzasadnienia, jeżeli AI będzie efektywnym narzędziem działającym według reguł ustalonych przez człowieka. Odnosząc się bezpośrednio do zastosowania sztucznej inteligencji w zakresie rozwiązywania (rozstrzygania) sporów cywilnych, należy zwrócić uwagę, że nie stoi ono na przeszkodzie podstawowym zasadom prawa cywilnego procesowego, a wręcz przeciwnie może służyć wzmocnieniu w praktyce niektórych z nich. W tym względzie szczególnie należy zwrócić uwagę na: 1) zasadę prawdy - w obszarze pozyskiwania i przetwarzania danych dających pełniejszy obraz stanu faktycznego; 2) zasadę koncentracji materiału dowodowego - ze względu na szybkie i w wysokim stopniu niezawodne przetwarzanie danych, bez potrzeby nadmiernego angażowania czynnika ludzkiego (np. poprzez możliwość ograniczenia konieczności stosowania opinii biegłego sądowego); 3) zasadę kontradyktoryjności - AI pozwala na maksymalizowanie aktywności stron $\mathrm{w}$ dostarczaniu materiału procesowego, niwelując ich słabości w tym zakresie; 4) zasadę równości stron - sztuczna inteligencja niweluje różnice $\mathrm{w}$ potencjale poznawczym i ekonomicznym stron, działając w jednakowo efektywny sposób na rzecz każdej ze stron.

28 Zob. M. van der Put, B. Schellekens, Challenges and Opportunities...

29 H. Reese, AI Can Predict Outcome of Human Rights Trials, but Should It? [online], https://www.techrepublic.com/article/ai-can-predict-outcome-of-human-rights-trials-but-should-it/ [dostęp: 18.02.2020 r.]. 


\section{Zakończenie}

Obecny obraz wymiaru sprawiedliwości i wspierających ją systemów pozasądowych metod rozwiązywania sporów cywilnych wskazuje na potrzebę rozwoju zastosowań sztucznej inteligencji. Mamy do czynienia z przeciążonym, opartym na obrocie papierowymi dokumentami systemem, nieefektywnym oraz mało odpornym na błędy i dublowanie czynności, a z drugiej strony z ADR i ODR, które ciągle są w początkowej fazie rozwoju i budzą nieufność stron i pełnomocników procesowym w polskim systemie prawnym. W tym ostatnim obszarze potrzeba spektakularnych sukcesów pokazujących wyjątkową opłacalność wyboru pozasądowej metody rozwiązywania sporów cywilnych, a to może zapewnić właśnie sztuczna inteligencja.

Nie sposób nie zgodzić się ze stanowiskiem D. Coplina, że „sztuczna inteligencja zmieni nasze podejście do technologii. Zmieni nasze podejście do drugiego człowieka. Śmiem twierdzić, że zmieni nawet nasze postrzeganie istoty człowieczeństwa" ${ }^{\prime 30}$. Analizując przyszłość sztucznej inteligencji w zakresie rozstrzygania i rozwiązywania sporów cywilnych, również poza systemem wymiaru sprawiedliwości, należy przede wszystkim zdać sobie sprawę z konieczności dążenia do zbudowania w pełni obiektywnej sztucznej inteligencji, która będzie w stanie zapewnić wysoką jakość merytoryczną rozwiązań albo rozstrzygnięć kończących postępowanie. O tym decyduje algorytm działający w oparciu o zgromadzone i przetwarzane dane. W konsekwencji podstawowe znaczenie ma w odniesieniu do tej sfery wykorzystania AI odpowiednia wartość i właściwy dobór danych stanowiących podstawę działania sztucznej inteligencji. Im mniej wartościowe, przypadkowe albo wręcz zmanipulowane dane, tym mniejsza użyteczność sztucznej inteligencji dla poszukiwania optymalnego rozwiązania sporu cywilnego. Dlatego ten etap rozwoju maszyn nie może być traktowany mniej uważnie niż rozwój jej funkcjonalności, ponieważ będzie to oznaczało utratę stabilności fundamentów wykorzystania sztucznej inteligencji na potrzeby odciążenia wymiaru sprawiedliwości i tworzenia nowych alternatywnych metod rozwiązywania sporów

30 S. Shead, Sztuczna inteligencja to najważniejsza z obecnie rozwijanych na świecie technologii [online], serwis internetowy Business Insider Polska z dnia 19 czerwca 2016 r., https:// businessinsider.com.pl/technologie/nowetechnologie/sztuczna-inteligencja-to-najwazniejsza-rozwijana-obecnie-technologia/qscny5j [dostęp: 21.07.2019 r.]. 
cywilnych zarówno o charakterze judykacyjnym (różne formy arbitrażu) względnie koncyliacyjnym (mediacja i metody pokrewne).

W opinii Komisji Wolności Obywatelskich, Sprawiedliwości i Spraw Wewnętrznych Parlamentu Europejskiego podkreśla się odpowiedzialność podmiotów projektujących roboty i sztuczną inteligencję za opracowywanie nowych produktów w taki sposób, aby były bezpieczne, pewne i dostosowane do celu, a także zgodne z procedurami dotyczącymi przetwarzania, podlegającymi obowiązującym przepisom, zasadzie poufności, anonimowości, sprawiedliwego traktowania i rzetelnego procesu ${ }^{31}$. $\mathrm{Z}$ perspektywy standardów rzetelnego procesu, którego zaprzeczeniem jest nadmiernie obciążony i niewydolny wymiar sprawiedliwości, podstawowym aspektem zastosowania AI staje się wykorzystanie jej możliwości $\mathrm{w}$ poszczególnych sporach cywilnych $\mathrm{w}$ zakresie wzmacniania pożądanych cech postępowania cywilnego, takich jak krótszy czas postępowania, uproszczenie jego przebiegu, stworzenie systemu opartego w większym stopniu na wiedzy, wsparcie - a w dalszej perspektywie zastąpienie - mediatora albo arbitra.

Słowa kluczowe: sztuczna inteligencja, alternatywne metody rozwiązywania sporów cywilnych, mediacja, arbitraż

\section{Bibliografia}

\section{Źródła}

Rezolucja Parlamentu Europejskiego z dnia 16 lutego 2017 r. zawierająca zalecenia dla Komisji w sprawie przepisów prawa cywilnego dotyczących robotyki (2015/2103 (INL)), Dz. Urz. UE C 252 z 18.07.2018, s. 239-257.

Danis S., J. Ruska, Latvia: State of Art: Where Are We, Where Do We Want to Go?, https:/ / rm.coe.int/latvia-state-of-art-where-are-we-where-do-we-want-to-go-/16808e4d84 [dostęp: 14.06 .2019 r.].

Parlament Europejski, Kodeks postępowania etycznego dla inżynierów robotyki, załącznik do rezolucji Parlamentu Europejskiego z dnia 16 lutego 2017 r.

31 Zob. opinia Komisji Wolności Obywatelskich, Sprawiedliwości i Spraw Wewnętrznych (23.11.2016) dla Komisji Prawnej zawierająca zalecenia dla Komisji w sprawie przepisów prawa cywilnego dotyczących robotyki (2015/2103(INL)), http://www.europarl. europa.eu/doceo/document/A-8-2017-0005_PL.html\#title5 [dostęp: 30.07.2019 r.]. 
zawierającej zalecenia dla Komisji w sprawie przepisów prawa cywilnego dotyczących robotyki (2015/2103(INL)), Dz. Urz. UE C 252 z 18.07.2018, s. 239-257, http://www.europarl.europa.eu/doceo/document/TA-8-2017-0051_ PL.html?redirect [dostęp: 28.07.2019 r.].

\section{Literatura}

Aletras N. i in., Predicting Judicial Decisions of the European Court of Human Rights: A Natural Language Processing Perspective [online], Peer] Computer Science 2016 2:e93, https:/ / doi.org/10.7717/peerj-cs.93 [dostęp: 11.07.2019 r.].

Baran K.W., Mediacja w sprawach z zakresu prawa pracy, Praca i Zabezpieczenie Społeczne 2006, nr 3.

Białecki M., Mediacja w postępowaniu cywilnym, Warszawa 2012.

Bieliński A., Mediator w sprawach cywilnych - wybrane zagadnienia regulacji obcych i polskich, ADR. Arbitraż i Mediacja 2008, nr 3.

Błaszczak Ł., Alternatywne formy rozwiązywania sporów - analiza zjawiska na tle prawapolskiego, w: Czterdziestolecie kodeksu postępowania cywilnego. Zjazd Katedr Postępowania Cywilnego w Zakopanem (7-9.10.2005 r.), red. I. Ratusińska, Kraków 2006.

Golat R., Polubowne rozstrzyganie sporów, Warszawa 2007.

Gmurzyńska E., Kierunki rozwoju mediacji sądowej w sprawach cywilnych w USA i w Europie, Europejski Przegląd Sądowy 2006, nr 11.

Gmurzyńska E., Mediacja w sprawach cywilnych w amerykańskim systemie prawnym - zastosowanie w Europie i w Polsce, Warszawa 2007.

Gójska A., V. Huryn Mediacja w rozwiązywaniu konfliktów rodzinnych, Warszawa 2007.

Grove R., AI, Machine Learning and the Administration of Justice in England and Wales: Prospects, Opportunities, Challenges [online], https://rm.coe.int/ai-machine-learning-and-the-administration-of-justice-in-england-and-w/16808e4d87 [dostęp: 24.07.2019 r.].

Jakubiak-Mirończuk A., Alternatywne a sądowe rozstrzyganie sporów sądowych, Warszawa 2008.

Kalisz A., A. Zienkiewicz, Mediacja sądowa i pozasądowa. Zarys wykładu, Warszawa 2009.

Katz D.M., M.J. Bommarito II, J.Blackman, Predicting the Behavior of the Supreme Court of the United States: A General Approach [online], https://arxiv.org/ abs/1407.6333 [dostęp: 23.07.2019 r.].

Mazurek A., Najnowsze badania pokazuja jak sztuczna inteligencja pokonuje prawników [online], serwis internetowy Generacja Smart z dnia 21 maja 2018 r., https:/ / generacjasmart.pl/2018/05/21/sztuczna-inteligencjapokonuje-prawnikow / [dostęp: 12.12.2018 r.].

Mediacje. Teoria i praktyka, red. E. Gmurzyńska, R. Morek, Warszawa 2009. 
Opinia Komisji Wolności Obywatelskich, Sprawiedliwości i Spraw Wewnętrznych (23.11.2016) dla Komisji Prawnej zawierająca zalecenia dla Komisji w sprawie przepisów prawa cywilnego dotyczących robotyki (2015/2103(INL)), http:/ / www.europarl.europa.eu/doceo/document / A-82017-0005_PL.html\#title5 [dostęp: 30.07.2019 r.].

Morek R., O potrzebie popularyzacji nowych koncepcji i metod rozwiązywania sporów, Palestra 2007, nr 7/8.

Morek R., Razem czy osobno: uwagi o znaczeniach pojęć mediacji i koncyliacji, w: Sądy polubowne i mediacje, red. J. Olszewski, Warszawa 2008.

Nowak J., Systemy ekspertowe. Podstawowe pojęcia, geneza, metody wnioskowania, PC-Shell [online], http://zsi.tech.us.edu.pl/ nowak/psiise/psiise_2.pdf [dostęp: 13.07.2019 r.].

Pinker S., The Language Instinct, How the Mind Creates Language, New York 2010. Przybyła-Basista H., Mediacje rodzinne w konflikcie rozwodowym, Katowice 2006.

Put M. van der, B. Schellekens, Challenges and Opportunities of AI in the Judicial Systems. Reflections from the Netherlands [online], https://rm.coe.int/challenges-and-opportunities-of-ai-in-the-judicial-system-reflections-/16808e4d88 [dostęp: 13.07.2019 r.].

Reese H., AI Can Predict Outcome of Human Rights Trials, but Should It? [online], https://www.techrepublic.com/article/ai-can-predict-outcome-of-human-rights -trials-but-should-it/ [dostęp: 18.02.2020 r.].

Shead S., Sztuczna inteligencja to najważniejsza z obecnie rozwijanych na świecie technologii [on-line], serwis internetowy Business Insider Polska z dnia 19 czerwca 2016 r., https://businessinsider.com.pl/technologie/nowetechnologie/ sztuczna-inteligencja-to-najwazniejsza-rozwijana-obecnie-technologia/qscny5j [dostęp: 21.07.2019 r.].

Słownik [online], serwis internetowy SI Sztuczna Inteligencja, https://www. sztucznainteligencja.org.pl/slownik/ [dostęp: 20.07.2019 r.].

South J., A. Rogers, What Might Artificial Intelligence Mean for Alternative Dispute Resolution? [online], serwis internetowy Kluwer Mediation Blog z dnia 30 sierpnia 2018 r., http://mediationblog.kluwerarbitration. com/2018/08/30/might-artificial-intelligence-mean-alternative-dispute-resolution/ [dostęp: 13.05.2019 r.].

Stawa G., How Is Austria Approaching AI Integration into Judicial Policies [online], https:/ / rm.coe.int/how-is-austria-approaching-ai-integration-into-judicial-policies-/16808e4d81 [dostęp: 16.07.2019 r.].

Strategia BATNA [online], serwis internetowy Encyklopedia zarządzania, https:/ / mfiles.pl/pl/index.php/Strategia_BATNA [dostęp: 22.07.2019 r.].

Weitz K., Mediacja w sprawach gospodarczych, w: T. Wiśniewski i in., Postepowanie sadowe w sprawach gospodarczych, t. 7, Warszawa 2007. 


\section{APPLICATION OF ARTIFICIAL INTELLIGENCE IN THE OUT-OF-COURT RESOLUTION OF CIVIL DISPUTES}

\section{Sum mary}

The article elaborates upon the extent and ways of using artificial intelligence (AI) in the out-of-court resolution of civil disputes. The author analyses the areas in which AI may be used, ranging from collecting data and related processing for the needs of the decision-making process, through supporting mediators (conciliators) or arbitrators in the course of proceedings, to the role with a high degree of independence, referring to proposing possible solutions to the parties in the course of conciliation proceedings and even dispute settlement by issuing an arbitration binding on the parties. The study indicates not only the opportunities related to the complementary role of $\mathrm{AI}$ in relation to human activity in this area, but also the problems and threats related primarily to AI's weaknesses in the scope of the analysis of human behaviour and nuances related to human emotions and motivation in civil cases.

Key words: artificial intelligence, alternative methods of resolving civil disputes, mediation, arbitration

\section{ИСПОЛЬЗОВАНИЕ ИСКУССТВЕННОГО ИНТЕЛЛЕКТА ПРИ ВНЕСУДЕБНОМ РАЗРЕШЕНИИ ГРАЖДАНСКИХ СПОРОВ}

\section{Резюме}

В статье рассматриваются масштабы и способы использования искусственного интеллекта при внесудебном разрешении гражданских споров. Автор анализирует области, в которых ИИ может использоваться, начиная от сбора и обработки данных для нужд процесса принятия решений, поддержки переговорщиков или арбитров в ходе разбирательства, до роли с высокой степенью независимости, состоящей в предложении сторонам возможных решений в ходе примирительной процедуры, и даже урегулирования спора путем вынесения обязательного для сторон арбитражного решения. Исследование указывает не только на возможности, связанные с дополняющей ролью ИИ в отношении человеческой деятельности в этой области, но также на проблемы и нежелательные последствия, связанные, прежде всего, со слабостями ИИ в области анализа поведения человека и нюансов, опосредованных эмоциями и мотивировкой человека в делах гражданского характера.

Ключевые слова: искусственный интеллект, альтернативные методы разрешения гражданских споров, медиация, арбитраж 